\title{
THE EFFECT OF EXTERNAL TRANSPORT ON ENERGETIC EFFICIENCY OF BIODIESEL PRODUCTION
}

\author{
Olga Orynycz' ${ }^{1}$, Andrzej Wasiak ${ }^{1}$ \\ 1 Bialystok University of Technology, Production Management Dept., Wiejska 45A Str., 15-351 Bialystok, Poland, \\ e-mail: o.orynycz@pb.edu.pl, a.wasiak@pb.edu.pl
}

Received: 2016.10 .27

Accepted: 2017.12.16

Published: 2017.03.01

\begin{abstract}
In several our publications energetic efficiency of biofuel production was defined as a ratio of the amount of energy obtained in a form of biofuel to the sum of energy contributions necessary to conduct production processes on all the production stages. It was also shown that such a definition enables subsequent inclusion of production steps due to additivity of reciprocals of energetic efficiency determined separately for each step. In the present work, several scenarios of the transport of biomass between plantation and industrial facility converting biomass into biofuel are considered, appropriate values of energetic efficiency are computed and compared. The analysis is confined to biodiesel production based on rapeseed. The results show substantial differences caused by various approaches to that stage of transport.
\end{abstract}

Keywords: biodiesel, biofuel production, mathematical modelling, rapeseed

\section{INTRODUCTION}

In recent years biofuels reached strong share in fuels market, and also achieved substantial scientific interest. Various biological resources [Nigam and Singh 2011], including seeds, fruits and other parts of various plants, animal fat, etc. are taken into account for conversion into biofuel, also several technologies of conversion have appeared [Bharathiraja et al. 2014, Abnisa et al. 2011, Russo et al. 2012, Malakul et al. 2010]. Concerning reasons of such a situation, mitigation of carbon dioxide emission and gradual substitution of fossil fuels before their depletion are usually indicated.

Energetic yield of many plants is also discussed [Talens et al. 2007, Liao et al. 2011, Schneider et al. 2009, Singh et al. 2008, Smith et al. 2008], and frequently it is related to eventual effects on sustainability of the economy. EROEI - "Energy return on energy invested" is mostly considered as quantitative indicator of sustainability and quality of energy production systems, although not all authors agree to accept its correctness. Expectations that biofuels become a factor assuring mitigation of $\mathrm{CO}_{2}$ emission, as well as showing sufficient potential for meeting future energy demands are expressed in the paper [Arodudu and Ibrahim 2014]. The work estimates the actual share of biofuels in global primary energy consumption as $10 \%$, and having $80 \%$ share in total renewable energy production. Several works [Mediavilla et al. 2013, Marklein et al. 2010, Field et al. 2007], however, indicate several problems - namely either too large energy consumption during production of particular crops or not sufficient availability of arable land to satisfy global energy demand, especially because of competition with food production. Both factors might be considered as limits for expansion of biofuel production.

In several earlier works we have elaborated the method of computation of energetic efficiency, as a characteristic corresponding to EROEI, but more precisely defined [Zhang et al. 2013, Murphy et al. 2011, Wasiak and Orynycz 2014, Wasiak and Orynycz 2015].

The aim of the present paper is an attempt to evaluate the effect energy consumed in external transport i.e. the transport of biomass from agri- 
cultural plantation to industrial facility converting biomass into biofuel, on energetic efficiency of biofuel production system.

The approach consist in numerical analysis of virtual case studies, based upon choices of possibly realistic characteristics of transportation means, and the use of several transportation means driven on various distances between plantation and industrial facility

The new model of energetic efficiency of biofuel agricultural production system was introduced in [Wasiak and Orynycz 2014, Wasiak and Orynycz 2015, Orynycz and Wasiak 2015]. Energetic effectiveness, $\varepsilon$, related to one production year of agricultural subsystem, can be presented as follows:

$$
\varepsilon=\frac{E_{b i o}}{E_{e x}+E_{t r, \text { int }}+E_{e m b}}
$$

where: $E_{b i o}$ - is energy obtained from the field, $E_{e x}-$ is energy expended on tillage operations,

$E_{t r \text { int }}$ - is energy consumed for transportation outside of fields, but inside of the plantation,

$E_{\text {emb }}$ - is a fraction of embodied energy contained in production means, that is spend during tillage operations and transport executed during production year.

The value, $E_{b i o}$, in the numerator of the formula is the one obtained at the end of production system (including all subsystems existing) i.e. it corresponds to the energy contained in the final biofuel obtained from biomass originated at agricultural subsystem being under consideration. The obtained value characterizes efficiency of agricultural subsystem in an indirect way. It, however, offers the method of estimation of total efficiency, $\varepsilon_{t o t}$, of a system built of several subsystems being connected in series e.g. agricultural and industrial subsystems. The derived addition rule is given as

$$
\frac{1}{\varepsilon_{t o t}}=\sum_{i=1}^{I} \frac{1}{\varepsilon_{i}}
$$

where: $\varepsilon_{i},-$ are the values of efficiency determined for individual subsystems or individual operations performed in the same subsystem.

The formula (2) offers a possibility to estimate separately the effects caused by various steps and factors occurring in the production systems.

\section{FORMULATION OF THE PROBLEM}

Biomass produced in agricultural subsystem has to be converted into biofuel in an appropriate industrial facility. In the present paper, industrial conversion, rather than individual, small scale production of biodiesel for in-house use, is taken into account. Consequently the biomass should be transported from plantation to the industrial facility.

Two approaches are considered; the first one is transportation of rapeseed grain separated from the straw, the other - transportation of raw oil pressed locally at the plantation. In both cases scraps formed during processing (straw in the first case, mill cake - in the second) are utilized or distributed locally, and do not taken into account in the energy balance.

The analysis is made under consideration of several transportation means and various plantation sizes, what gives various crop sizes. Characteristics of transportation means are given in the Table 1.

The data presented in Table 1 are taken from various catalogues, internet sites, etc. fuel consumption is assumed on the basis of average from various sources. Computations are performed in

Table 1. Characteristics of transportation means

\begin{tabular}{|l|c|c|c|c|c|}
\hline \multirow{2}{*}{} & \multicolumn{2}{|c|}{ Load capacity } & \multirow{2}{*}{ Fuel consumption } & \multicolumn{2}{c|}{$\begin{array}{c}\text { Ratio load capacity to fuel } \\
\text { consumption }\end{array}$} \\
\cline { 2 - 3 } \cline { 5 - 6 } & mass & volume & & mass & volume \\
\hline & $\mathrm{Mg}$ & $\mathrm{m}^{3}$ & $\mathrm{Mg} / / \mathrm{km}$ & $\mathrm{m}^{3} / / / \mathrm{km}$ \\
\hline Truck 3t & 3 & 28 & 0.12 & 26 & 234 \\
\hline Truck 8t & 8 & 45 & 0.24 & 34 & 188 \\
\hline Truck 24t & 24 & 80 & 0.72 & 34 & 112 \\
\hline Cistern 3000 & & 3 & 0.12 & & 26 \\
\hline Cistern 10000 & & 10 & 0.3 & & 34 \\
\hline
\end{tabular}


EXCEL (Microsoft) using a specially designed macro. Some calculations, and graphs are made in ORIGIN (Microcalc).

\section{RESULTS}

The numbers of cisterns needed to transport oil from small plantations are presented in Table 2 as a function of plantation area. The plantation area is given in hectares $\left(1 \mathrm{ha}=0.01 \mathrm{~km}^{2}\right)$.

It is evident that in small and relatively small plantations the amount of oil is small, and a cistern can be partially filled, what spoils fuel economy. The situation occurring in large plantations is illustrated in Table 3. Large number of cisterns in this case can be realized by multiple courses of a smaller number of cisterns. In this case, fractional numbers of cisterns are only a small contribution to the total number, and in practice, they should be compensated between cisterns. As it can be seen in Figure 1. The number of cisterns needed for crop transportation is a linear function of plantation size.

Transportation of rapeseed grains between plantation and industrial facility for small plantations obviously shows the same incomplete filling of trucks as it was seen in the case of cisterns for transportation of oil. The amounts of courses (or trucks) for large plantations is shown in Table 4.

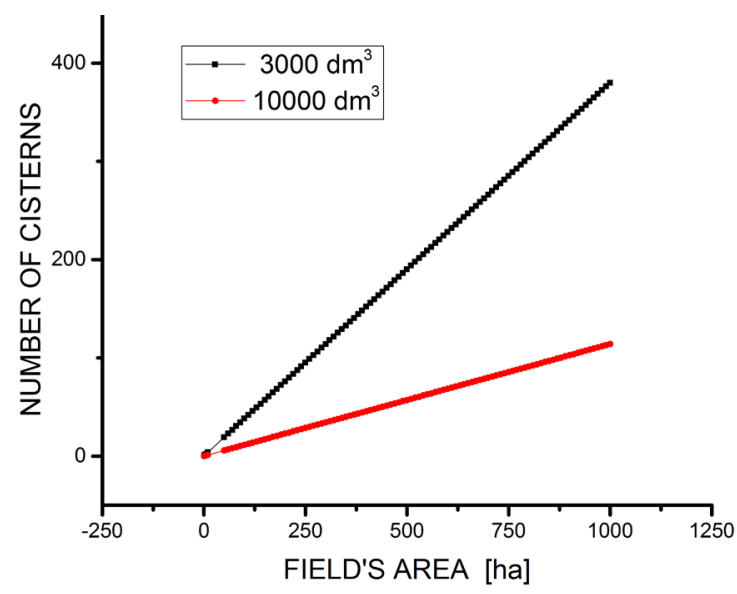

Figure 1. Number of cisterns needed for transportation of oil obtained by pressing rapeseed grains at plantation as a function of plantation size.

In the first view, it can be considered unexpected that oil, which consists only a part of rapeseed grains mass, requires a bigger number of transportation means than the grain itself.

This is a result of relatively small volume of cisterns being used in local transport than the volume load capacity of trucks that can be used in such transport conditions. Obviously the bigger volume of transportation unit is used, the smaller number of cars, or courses of the same car is needed. The plot, not shown here, also indicates a linear dependence of the number of trucks upon field's size.

Table 2. Number of cisterns for transportation of oil from small fields

\begin{tabular}{|c|c|c|c|c|}
\hline $\begin{array}{c}\text { Fields area } \\
{[\mathrm{ha}]}\end{array}$ & $\begin{array}{c}\text { Grain yield } \\
\mathrm{mg}\end{array}$ & $\begin{array}{c}\text { Oil yield } \\
\text { I }\end{array}$ & $\begin{array}{c}\text { Number of cisterns } \\
3000 \mathrm{I}\end{array}$ & $\begin{array}{c}\text { Number of cisterns } \\
10000 \text { I }\end{array}$ \\
\hline 1 & 3 & 1140 & 0.38 & 0.114 \\
\hline 2 & 6 & 2280 & 0.76 & 0.228 \\
\hline 5 & 15 & 5700 & 1.9 & 0.57 \\
\hline 10 & 30 & 11400 & 3.8 & 1.14 \\
\hline 50 & 150 & 57000 & 19 & 5.7 \\
\hline
\end{tabular}

Table 3. Number of cisterns for transportation of oil from large fields

\begin{tabular}{|c|c|c|c|c|}
\hline $\begin{array}{c}\text { Field's area } \\
{[\mathrm{ha}]}\end{array}$ & $\begin{array}{c}\text { Grain yield } \\
\mathrm{Mg}\end{array}$ & $\begin{array}{c}\text { Oil yield } \\
\mathrm{L}\end{array}$ & $\begin{array}{c}\text { Number of cisterns } \\
3000 \mathrm{I}\end{array}$ & $\begin{array}{c}\text { Number of cisterns } \\
10000 \text { I }\end{array}$ \\
\hline 200 & 600 & 228000 & 76 & 22.8 \\
\hline 300 & 900 & 342000 & 114 & 34.2 \\
\hline 400 & 1200 & 456000 & 152 & 45.6 \\
\hline 500 & 1500 & 570000 & 190 & 67 \\
\hline 600 & 1800 & 684000 & 228 & 79.8 \\
\hline 700 & 2100 & 798000 & 266 & 91.2 \\
\hline 800 & 2400 & 912000 & 304 & 102.6 \\
\hline 900 & 2700 & 1026000 & 342 & 114 \\
\hline 1000 & 3000 & 1140000 & 380 & \\
\hline
\end{tabular}


Table 4. Number of trucks for transportation of grain from large fields

\begin{tabular}{|c|c|c|c|c|c|}
\hline $\begin{array}{c}\text { Field's area } \\
\text { [ha] }\end{array}$ & $\begin{array}{c}\text { Grain } \\
\mathrm{mg}\end{array}$ & $\begin{array}{c}\text { Grain } \\
\mathrm{m}^{3}\end{array}$ & $\begin{array}{c}\text { Number } \\
3 \text { ton } \\
\text { truck's }\end{array}$ & $\begin{array}{c}\text { Number } \\
8 \text { ton } \\
\text { truck's }\end{array}$ & $\begin{array}{c}\text { Number } \\
24 \text { ton } \\
\text { truck }\end{array}$ \\
\hline 100 & 300 & 458 & 16.4 & 10.2 & 5.8 \\
\hline 200 & 600 & 916 & 32.8 & 20.4 & 11.5 \\
\hline 300 & 900 & 1374 & 49.1 & 30.6 & 17.2 \\
\hline 400 & 1200 & 1832 & 65.5 & 40.8 & 23 \\
\hline 500 & 1500 & 2290 & 81.8 & 50.9 & 28.7 \\
\hline 600 & 1800 & 2748 & 98.2 & 61.1 & 34.4 \\
\hline 700 & 2100 & 3206 & 114.6 & 71.3 & 40.1 \\
\hline 800 & 2400 & 3664 & 130.9 & 81.5 & 45.9 \\
\hline 900 & 2700 & 4122 & 147.3 & 91.7 & 51.6 \\
\hline 1000 & 3000 & 4580 & 163.6 & 101.8 & 57.3 \\
\hline
\end{tabular}

Fig. 2.a. shows a comparison between energy, $E_{b i o}$, that is the energy obtained from the field, and energy consumed during transportation by means of several types of trucks.

Since the plots for different trucks are not distinguishable in this plot, the consumed energy by different trucks is also presented in Figure 2.b. It is visible, that energy consumed is small as compared to energy produced. It has to be mentioned, however, that the energy consumed, as discussed here, is the only one from many contributions to the energy consumed in various processes during biofuel production. The contribution of transport to energetic efficiency can be estimated using partial energetic efficiency for transport only. That is obviously expressed as:

$$
\varepsilon_{t r}=\frac{E_{\text {bio }}}{E_{\text {tr,ext }}}
$$

a)

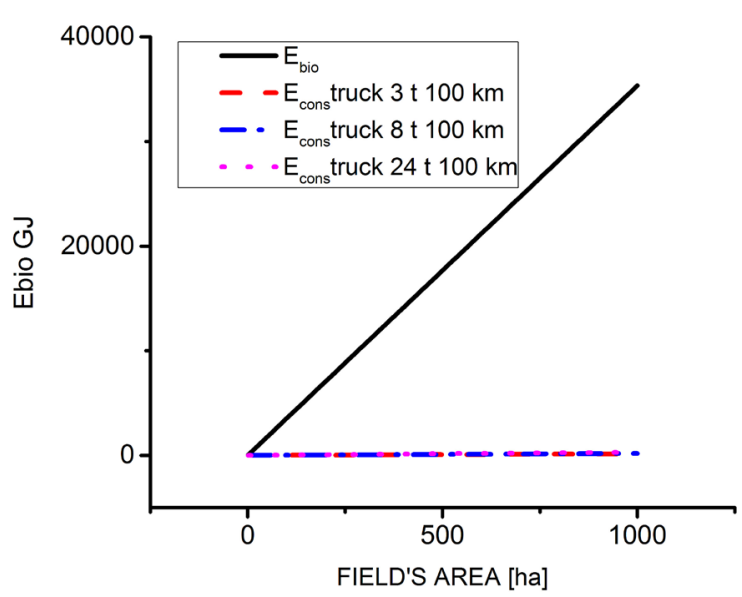

where: $E_{t r e x t}-$ is the described above energy consumed in external transport (i.e. from plantation to industrial facility).

As an example, the plot of this contribution presented as a function of plantation area is shown in Figure 3.

It is seen that only for very small plantations some increase of the efficiency is observed, while for the cases of large plantations the efficiency remains almost constant differing only between different transportation units. The initial increase can be attributed to an increase of the part of filling the loading capacity of a car. Values of this contribution to energy efficiency computed for small fields is given in Table 5 in comparison to selected large fields. It is seen that for small trucks initial values are much closer to those for large fields than for bigger trucks. This observation can be rationalized as a result of filling,

b)

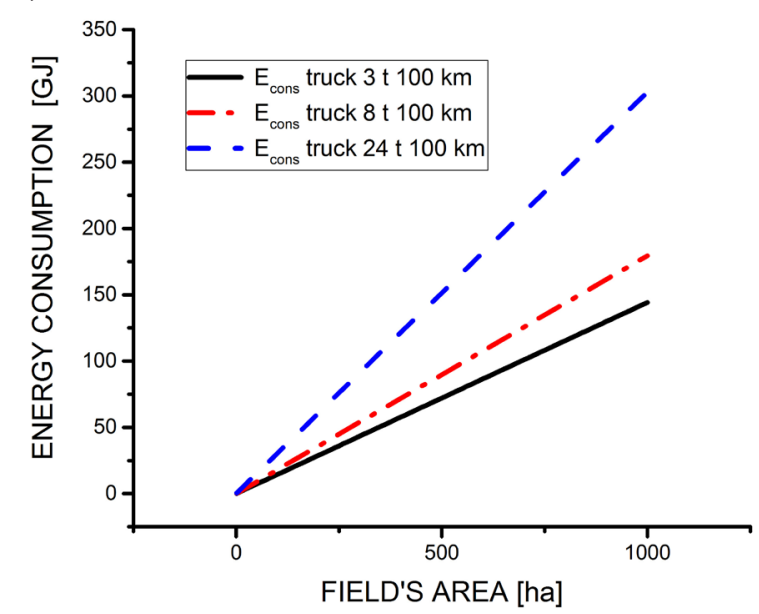

Figure 2. a) Energy produced in form of biofuel vs. energy consumed by trucks on the distance $100 \mathrm{~km}$, b) energy consumed for transportation on the distance $100 \mathrm{~km}$. 


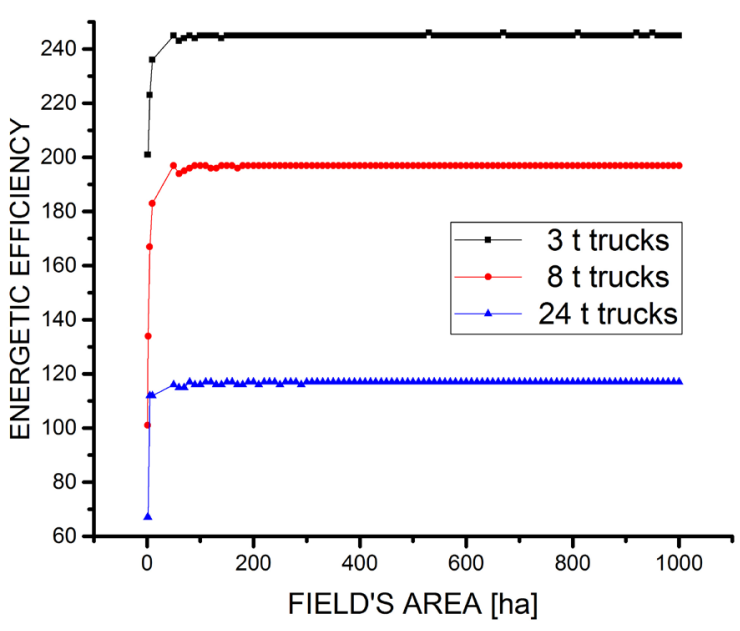

Figure 3. Contribution to energetic efficiency resulting from the use of different trucks on the distance $100 \mathrm{~km}$. (Initial increase of energetic efficiency with an increase of plantation sixe results of not complete loading of trucks with crops from small plantations)

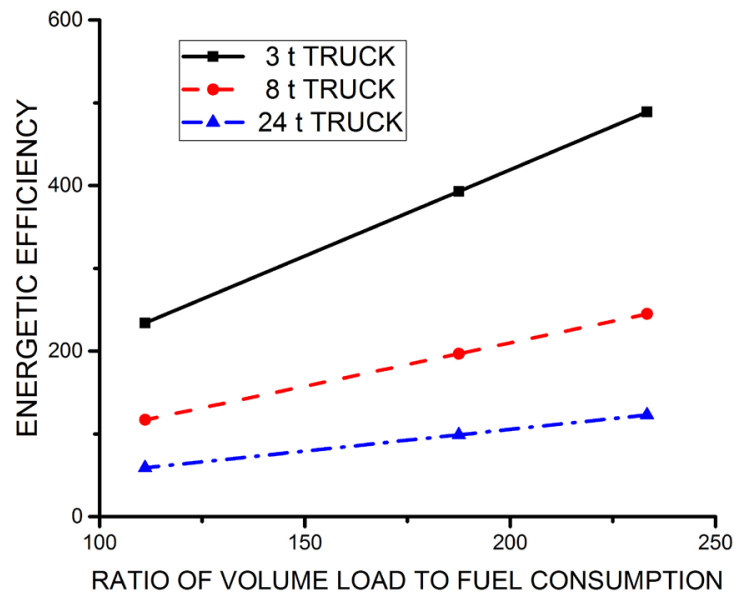

Figure 4. Correlation between energetic efficiency and ratio of volume load to fuel consumption of a truck

Table 5. Energetic efficiency for grain transportation from small fields compared to large one

\begin{tabular}{|c|c|c|c|c|c|c|c|c|c|}
\hline $\begin{array}{l}\text { Field's } \\
\text { area } \\
\text { [ha] }\end{array}$ & $\begin{array}{c}\varepsilon \\
3 \text { ton } \\
\text { trucks } \\
50 \mathrm{~km}\end{array}$ & $\begin{array}{c}\varepsilon \\
8 \text { ton } \\
\text { trucks } \\
50 \mathrm{~km}\end{array}$ & $\begin{array}{c}\varepsilon \\
24 \text { ton } \\
\text { trucks } \\
50 \mathrm{~km}\end{array}$ & $\begin{array}{c}\varepsilon \\
3 \text { ton } \\
\text { trucks } \\
100 \mathrm{~km}\end{array}$ & $\begin{array}{c}\varepsilon \\
8 \text { ton } \\
\text { trucks } \\
100 \mathrm{~km}\end{array}$ & $\begin{array}{c}\varepsilon \\
24 \text { ton } \\
\text { trucks } \\
100 \mathrm{~km}\end{array}$ & $\begin{array}{c}\varepsilon \\
3 \text { ton } \\
\text { trucks } \\
200 \mathrm{~km}\end{array}$ & $\begin{array}{c}\varepsilon \\
8 \text { ton } \\
\text { trucks } \\
200 \mathrm{~km}\end{array}$ & $\begin{array}{c}\varepsilon \\
24 \text { ton } \\
\text { trucks } \\
200 \mathrm{~km}\end{array}$ \\
\hline 1 & 401 & 201 & 134 & 201 & 101 & 67 & 101 & 51 & 34 \\
\hline 2 & 401 & 268 & 134 & 201 & 134 & 67 & 101 & 67 & 34 \\
\hline 5 & 446 & 334 & 223 & 223 & 167 & 112 & 112 & 84 & 56 \\
\hline 10 & 472 & 365 & 223 & 236 & 183 & 112 & 118 & 92 & 56 \\
\hline 50 & 489 & 393 & 231 & 245 & 197 & 116 & 123 & 99 & 58 \\
\hline 800 & 490 & 394 & 233 & 245 & 197 & 117 & 123 & 99 & 59 \\
\hline
\end{tabular}

namely the crop from small field fills much more loading capacity of a small truck than of a big truck, and therefore, the deviations from saturation value are smaller for small trucks and larger for the big ones.

As the other problem, the differences of energy efficiency between trucks differing in capacity may be considered. The explanation of the observed behavior can be given by correlation between energetic efficiency and ratio of volume load capacity to fuel consumption. It seems that this last parameter is responsible for energetic efficiency of a particular transportation unit.

Finally, to estimate the real influence of external transport on the total energetic efficiency of production system one has to calculate an example with the use of eq. 2. In our earlier works [Wasiak and Orynycz 2015, Orynycz and Wasiak 2015] we have estimated agricultural part of energetic efficiency as being between 10 and 200 depending on particular conditions of pro- duction technology. Basing on such an assumption, the final results are given in Table 6. As it is seen, apparently small energy consumption as compared to the production yield, in effect gives quite substantial decrease of the resulting global energetic efficiency.

\section{CONCLUSIONS}

The presented results show that the energy consumption during external transport from agricultural plantation to industrial facility may strongly reduce the global efficiency of the system. This energy consumption, in turn, depends on transportation means characteristic - mainly the ratio of volume capacity to fuel consumption per unit of the distance. The capacity of the transportation means also plays a substantial role in creating transport's contribution to energetic efficiency of the system. 
Table 6. Resulting energy efficiency of an agricultural subsystem coupled with external transportation system, both of various individual contributions

\begin{tabular}{|c|c|c|c|c|c|c|c|c|c|c|}
\hline & & \multicolumn{3}{|c|}{ External distance $50 \mathrm{~km}$} & \multicolumn{3}{|c|}{ External distance 100 km } & \multicolumn{3}{|c|}{ External distance 200 km } \\
\hline \multicolumn{2}{|c|}{$\varepsilon_{\text {agr }}$} & $\begin{array}{c}\varepsilon \\
3 \text { ton } \\
\text { trucks }\end{array}$ & $\begin{array}{c}\varepsilon \\
8 \text { ton } \\
\text { trucks }\end{array}$ & $\begin{array}{c}\varepsilon \\
24 \text { ton } \\
\text { trucks }\end{array}$ & $\begin{array}{c}\varepsilon \\
3 \text { ton } \\
\text { trucks }\end{array}$ & $\begin{array}{c}\varepsilon \\
8 \text { ton } \\
\text { trucks }\end{array}$ & $\begin{array}{c}\varepsilon \\
24 \text { ton } \\
\text { trucks }\end{array}$ & $\begin{array}{c}\varepsilon \\
3 \text { ton } \\
\text { trucks }\end{array}$ & $\begin{array}{c}\varepsilon \\
8 \text { ton } \\
\text { trucks }\end{array}$ & $\begin{array}{c}\varepsilon \\
24 \text { ton } \\
\text { trucks } \\
\end{array}$ \\
\hline \multicolumn{2}{|c|}{$\varepsilon_{i}$} & 489 & 393 & 231 & 245 & 197 & 116 & 123 & 99 & 58 \\
\hline 10 & $\varepsilon=$ & 9.8 & 9.8 & 9.6 & 9.7 & 9.6 & 9.3 & 9.3 & 9.1 & 8.6 \\
\hline 50 & $\varepsilon=$ & 8.2 & 8.2 & 8.1 & 8.2 & 8.1 & 7.9 & 7.9 & 7.7 & 7.4 \\
\hline 100 & $\varepsilon=$ & 7.6 & 7.6 & 7.5 & 7.6 & 7.5 & 7.4 & 7.4 & 7.2 & 6.9 \\
\hline 200 & $\varepsilon=$ & 7.4 & 7.4 & 7.3 & 7.4 & 7.3 & 7.2 & 7.2 & 7 & 6.7 \\
\hline
\end{tabular}

\section{Acknowledgements}

The research have been performed under financial support from Bialystok University of Technology. Statutory Research Project WZ/S/1/2015 financed from scientific grant from Ministry of Science and Higher Education (MNiSW).

\section{REFERENCES}

1. Abnisa F., Wan Daud W.M.A., Husin W.N.W., Sahu J.N. 2011. Utilization possibilities of palm shell as a source of biomass energy in Malaysia by producing bio-oil in pyrolysis process. Biomass and Bioenergy 35, 1863-1872.

2. Arodudu O., Ibrahim E., Voinov A., Duren I. 2014. Exploring bioenergy potentials of built-up areas based on NEG-EROEI indicators, Ecological Indicators 47, 67-79.

3. Bharathiraja B., Chakravarthy M., RanjithKumar R. Yuvaraj D., Jayamuthunagai J., Praveen Kumar R., Palani S. 2014. Biodiesel production using chemical and biological methods - A review of process, catalyst, acylacceptor, source and process variables, Renewable and Sustainable Energy Reviews 38, 368-382.

4. Field C., Campbell J., Lobell D. 2007. Biomass energy: the scale of the potential resource, Trends in Ecology and Evolution 23, 65-72.

5. Liao W., Heijungs R., Huppes G. 2011. Is bioethanol a sustainable energy source? An energy-, exergy-, and emergy-based thermodynamic system analysis, Renewable Energy 36, 3479-3487.

6. Malakul P., Papong S., Chom-in T., Noksa-n S. 2010. Life cycle energy efficiency and potentials of biodiesel production from palm oil in Thailand. Energy Policy 38, 226-233.

7. Marklein D. M., Thoth M.A., Karpoff M.N., Paul G.S, McCormack R., Kyriazis J., Krueger T. 2010, Food versus biofuels: environmental and economic costs, Human Ecology 37, 1-12.

8. Mediavilla M., deCastro C., Capella'n I., Miguel L.J., Arto I., Frechoso F. 2013. The transition towards renewable energies: Physical limits and temporal conditions, Energy Policy 52, 297-311.
9. Murphy D.J., Hall C.A.S., Dale M., Cleveland C. 2011. Order from Chaos: A Preliminary Protocol for Determining the EROI of Fuels, Sustainability 3, 1888-1907.

10. Nigam P.S., Singh A. 2011. Production of liquid biofuels from renewable resources, Progress in Energy and Combustion Science 37, 52-68.

11. Orynycz O., Wasiak A. 2015. Effects of field's topology on energetic efficiency of rapeseed plantation for biofuel production. Applied Computer Science 11, 83-98.

12. Russo D., Dassisti M., Lawlorb V., Olabib A.G. 2012. State of the art of biofuels from pure plant oil, Renewable and Sustainable Energy Reviews 16, 4056-4070.

13. Schneider U., Smith A. 2009, Energy intensities and greenhouse gas emission mitigation in global agriculture, Energy Efficiency 2, 195-206.

14. Singh K.P., Prakash V., Srinivas K.P.K., Srivastva A.K. 2008. Effect of tillage management on energy-use efficiency and economics of soybean (Glycine max) based cropping systems under the rainfed conditions in North-West Himalayan Region, Soil \& Tillage Research 100, 78-82.

15. Smith S.L., Thelen K.D., MacDonald S.J. 2013. Yield and quality analyses of bioenergy crops grown on a regulatory brownfield, Biomass and Bioenergy 49, 123-130.

16. Talens L., Villalba G., Gabarrell X. 2007, Exergy analysis applied to biodiesel production, Resources, Conservation and Recycling 51, 397-407.

17. Wasiak A., Orynycz O. 2014. Formulation of a model for energetic efficiency of agricultural subsystem of biofuel production, IEEE International Energy Conference: ENERGYCON'2014, Dubrovnik, Croatia, 1333-1337.

18. Wasiak A., Orynycz O. 2015. The effects of energy contributions into subsidiary processes on energetic efficiency of biomass plantation supplying biofuel production system. Agriculture and Agricultural Science Procedia 7, 292-300.

19. Zhang Y., Colosi L.M. 2013. Practical ambiguities during calculation of energy ratios and their impacts on lifecycle assessment calculations, Energy Policy 57, 630-633. 